\title{
Efektifitas Penggunaan Fitur Instagram Dalam Meningkatkan Pertemanan Remaja SMA Negeri 1 Maros Di Era Digital
}

\author{
Muhammad Iqbal Sultan \\ miqsul@yahoo.com. \\ Universitas Hasanuddin, Jalan Perintis Kemerdekaan KM10, Tamalanrea, Makassar
}

Submitted: 23 September 2020 Revised: 24 November 2020 Accepted : 07 December 2020

\begin{abstract}
Abstrak
Perkembangan teknologi media baru menghadirkan media sosial, khususnya Instagram untuk berbagi informasi dan pemenuhan kebutuhan pertemanan di kalangan remaja millenial di era digital. Instagram salah satu jenis media sosial yang saat ini banyak digunakan remaja, bukan hanya sebagai ruang pribadi melainkan ruang publik bagi remaja. Remaja menghabiskan waktu ber jam-jam untuk menggunakan media sosial ini, untuk berbagi gambar, foto, video, melihat-lihat, berkomentar di akun dan meningkatkan pertemanan. Tujuan penelitian ini adalah untuk mengetahui efektifitas fitur pertemanan Instagram remaja di era digital. Metode penelitian menggunakan kuantitatif deskriptif jenis pendekatan survey kalangan remaja millennial pengguna Instagram. Teknik penarikan sample random proporsional sampling dan penentuan jumlah sampel menggunakan Isaac dan Michael taraf kesalahan 5\% dipilih sebanyak 67 responden remaja SMA Negeri 1 Maros. Teknik pengumpulan data melalui kuesioner dan studi kepustakaan yang relevan dengan penelitian. Hasil penelitian menunjukkan sangat efektif dalam penggunaan fitur Instagram dalam meningkatkan pertemanan remaja SMA Negeri 1 Maros dalam tahapan interest adalah $61.2 \%$. Efektifnya dalam durasi dan intensitas penggunaan, tahapan desire sebesar 25,4\% dalam proses komunikasi dalam konteks pertemanan, melalui fitur Instagram Stories, dibandingkan fitur Arsip Cerita, Explore, Live Video, Instagram Stories, Close Friends, dan Sorotan. Tahapan action sebesar $64,2 \%$ untuk Fitur ini memberikan konsep penyingkapan diri dan kenyamanan mengunggah Instagram Stories dalam proses pertemanan mereka tanpa harus mencari informasi melalui media lain. Tingkat keterbukaan dan faktor kedekatan (proksimity) dalam memilih dan membagikan unggahan, privasi, dan kebebasan memilih teman yang diinginkan dalam proses meningkatkan pertemanan.
\end{abstract}

Kata kunci: Fitur close friends, media sosial instagram, pertemanan remaja, era digital

\section{Effectiveness Of Instagram Feature Utilization In Improving The Friendship of SMA 1 Maros Teenagers in The Digital Era}

\begin{abstract}
The development of new media technology presents social media, especially Instagram to share information and meet the needs of friendship among millennial teenagers in the digital age. Instagram is one type of social media that is currently widely used by teenagers, not just as a private space but a public space for teenagers. Teenagers spend hours using this social media, to share pictures, photos, videos, look around, comment on accounts and improve friendships. The purpose of this study was to find out the effectiveness of teen Instagram friendship features in the digital age. The research method uses a descriptive quantitative type of survey approach among millennial teen Instagram users. Random sample withdrawal techniques proportional sampling and determination of the number of samples using Isaac and Michael error level 5\% selected as many as 67 respondents sma Negeri 1 Maros teenagers. Data collection techniques through questionnaires and literature studies relevant to research.

Very effective in the use of Instagram features in improving the friendship of teenagers SMA Negeri 1 Maros in the interest stage is $61.2 \%$. Effectively in duration and intensity of use, desire stages by $25.4 \%$ in the communication process in the context of friendships, through the Instagram Stories feature, compared to the Story Archive, Explore, Live Video, Instagram Stories, Close Friends, and Highlights features. The 64.2\% action stage for this feature provides the concept of self-disclosure and the convenience of uploading Instagram Stories in the process of their friendship without having to search for information through other media. The level of openness and proximity factor (proximity) in choosing and sharing uploads, privacy, and freedom of choice of friends desired in the process of improving friendships.
\end{abstract}


Key words: close friends features, digital age, social media instagram, teen friendship

\section{PENDAHULUAN}

Perkembangan teknologi era digital menghadirkan internet sebagai digital baru yang berfungsi menghubungkan pengguna tanpa dibatasi jarak, ruang dan waktu sehingga arus informasi pun semakin cepat. Hal inilah yang menyebabkan manusia cenderung berkomunikasi satu sama lain tanpa ada batasan, dengan kemudahan inilah membuat jutaaan orang di dunia saling berinteraksi menggunakan internet, sehingga terbentuk situs media sosial.

Situs media sosial sebagai media komunikasi antara individu dalam dunia maya untuk saling bertukar informasi, saling berbagi, dan jalin hubungan ikatan personal antara satu pengguna dengan pengguna lainnya. Berdasarkan data tahun 2020 terdapat 175,4 juta pengguna internet di Indonesia (APJJI, 2020). Hasil survey lainnya, untuk data secara keseluruhan populasi Indonesia yang berjumlah 272,1 juta jiwa, mengindikasikan ada $64 \%$ atau setengah penduduk Indonesia telah merasakan akses dunia maya. dikutip dalam (APPJI, 2020).

Media sosial merupakan media online yang memudahkan para penggunanya saling berkomunikasi, menciptakan dan berbagi pesan antar pengguna yang terhubung melalui jaringan media online. Dengan kata lain, media sosial dapat berupa komunikasi yang dimediasi komputer di mana individu tidak hanya mengatur profil untuk menyajikan siapa mereka tetapi juga menghasilkan konten mereka sendiri, melihat, dan berinteraksi dengan konten teman-teman mereka atau pengguna lain secara online (Carr \&amp; Hayes, 2015). Situs jejaring sosial (SNSs), subdomain media sosial, telah didefinisikan sebagai:

a networked communication platform in which participants 1) have uniquely identifiable profiles that consist of user-supplied content, content provided by other users, and/or system-provided data; 2) can publicly articulate connections that can be viewed and traversed by others; and 3) can consume, produce, and/or interact with streams of user-generated content provided by their connections on the site. (Ellison \& boyd, 2013)

Pengguna dapat menggunakan profil pribadi atau akun pribadinya untuk saling berkomunikasi dengan sesama pengguna media sosial ini, seperti, friendster, facebook, linkedin, foursquare, myspace, twitter, line, path, instagram, snapchat, askfm menjadi trend di kalangan masyarakat, khususnya remaja kategori generasi millennial di era digital.

Instagram merupakan situs jejaring media sosial yang sangat popular dan digunakan pada remaja. Kelebihan aplikasi media Instagram sebagai media komunikasi dalam mengirimkan informasi gambar foto bersifat interaktif melalui fitur foto sharing, mengambil foto, menerapkan filter digital dan membagikannya diantara para pengguna melalui smartphone masing-masing. Penggunaan instagram menempati posisi kedua setelah facebook (APJJI, 2018).

Instagram sebagai aplikasi sharing foto mengalami perkembangan sejak 2010, data pengguna aktif sebanyak 500 juta, penggunaan fitur Instagram berfokus pada foto dan video durasi pendek dan bersifat timbal balik antara para pengguna. Dominasi penggunaan 
Instagram terpopuler pada usia remaja antara 18-29 tahun sebanyak 59\% (A. Jackson, 2017). Jenis media komunikasi berbasis internet di era digital, dimana komunitas usia remaja tersebut memilih menggunakan berdasarkan kesadaran diri sendiri dan untuk saling berkomunikasi tanpa dibatasi ruang dan waktu (Phatiningsih, 2017).

Instagram sampai saat ini berkembang pesat dengan segala inovasi fitur-fitur baru yang terus bermunculan, yaitu dengan adanya instastory, fitur simpan (archive), inner circle, dan instagram promote menjadi kelebihan tersendiri (Maryolein, S., dkk, 2019). Misalnya, dalam hal pertemanan, pengguna bisa menjadi pengikut atau followers bagi pengguna lainnya, selanjutnya saling berkomunikasi, berbincang, membagi foto atau video dan jika followers, menyukai 'like' dan memberikan umpanbalik melalui komentar pada foto atau video tersebut.

Pengguna instagram juga bisa mengunggah foto atau video sebagai pesan kepada pengguna lainnya, tampilan fitur aplikasi efek foto/video, judul foto, hashtag, lokasi dan tandai teman, explore atau kumpulan instagram stories, foto dan video dari akun bersifat pribadi berdasarkan pilihan pengguna.

Instagram sebagai media komunikasi digunakan dilatarbelakangi jenis-jenis kebutuhan setiap pengguna maupun pengguna lainnya, utamanya kebutuhan memperoleh informasi. Penjelasan Guha (dalam Syaffril, 2004) bahwa terdapat jenis-jenis kebutuhan informasi, yaitu: current need approach, everyday need approach, exhaustic need approach, dan catchingup need approach (Nofha Rina, 2020)

Instagram kategori jejaring sosial yang dapat diakses dengan mudah, dan dapat memberikan informasi dan salah satu media sosial sangat sering dikunjungi sekaligus pengguna bisa memilih orang yang bisa diajak gabung sebagai teman, untuk berbagai kegiatan, dengan cara memposting kegiatan dalam bentuk foto dan video.

Namun demikian, instagram dinilai bisa juga berdampak psikologi terburuk. Penjelasan Sydney Morning Herald, dikutip Dari (2019) bahwa instagram diklaim bisa menurunkan kualitas tidur, kecemasan, menjadi wadah bullying, pembentukan citra tubuh yang salah, dan FOMO (fobia ketinggalan berita di jejaring sosial).

Salah satu penggunaan instagram untuk menghindari dampak negatif dalam penggunaan instagram, remaja millenial, khususnya remaja SMA Negeri 1 Maros menggunakan fitur instagram, khsusunya penggunaan fitur closed friend untuk pertemanan, berkomunikasi untuk saling berbagi pengalaman. Seperti, mengunggah foto atau video pertemanan yang hanya dapat dilihat berdasarkan pilihan followers mereka. Kelebihan Fitur close friends adalah pilihan bagi pengguna Instagram untuk memilih teman yang bisa melihat unggahannya. Fitur instagram ini media komunikasi remaja untuk saling terbuka, berinteraksi sosial dan mengunggah personal dirinya pada teman yang dikenalnya, seperti berisi curahan hati yang berbentuk kata-kata yang di dapat dari akun instagram penyedia quotes-quotes, swafoto dan video diri khusus di fitur close friends.

Pendekatan Teori Uses and Gratifications mengasumsikan bahwa pengguna mempunyai pilihan alternatif untuk memenuhi kebutuhannya. Penggunaan media komunikasi berusaha mencari sumber media yang paling baik dalam usaha memenuhi kebutuhannya (Nurudin, 2009:1992). Penggunaan fitur ini menjadi alternatif pemenuhan kebutuhan sosial melalui fitur pertemanan di Instagram di kalangan remaja dan 
memanfaatkan penggunaan fitur Instagram tersebut untuk mengakrabkan hubungan pertemanan.

Penelitian sebelumnya menunjukkan bahwa fitur close friends melalui studi naratif remaja berkepribadian introvert di Instagram komunitas everlasting friends (Syahrul, 2019). Remaja berkepribadian introvert memilih menggunakan fitur close friends instagram karena dapat memilih individu yang bisa melihat story unggahannya. Penyebab terbentuknya kepribadian introvert adalah tingginya rasa takut dan penilaian negatif, rasa tidak aman jika tidak ada kedekatan hubungan individu yang melihat unggahannya di sosial media.

Penelitian ini berfokus pada efektivitas fitur-fitur instagram, seperti aplikasi efek foto/video, judul foto, hashtag, lokasi dan tandai teman, explore, instagram stories, close friends yang spesifik memilih pengguna. Dalam teori pengembangan hubungan seperti pemanfaatan pertemanan di instagram dapat membuka informasi dan wawasan dengan mengunggah foto dan komentari orang lain (Mahendra. B, 2017).

Efektifitas penggunaan fitur instagram dalam jalain pertemanan ini merujuk pada penjelasan Stevani R (2013), bahwa pesan yang efektif dari model AIDA memenuhi karakteristik sebagai berikut: (1) Menimbulkan perhatian (Attention), informasi harus menarik perhatian, khalayak sasarannya, baik pembaca, pendengar atau pemirsa. Sangat diperlukan gambar atau tulisan yang menyolok, lagu yang menarik, serta kata-kata yang mengandung janji, jaminan, keistimewaan dan lain-lain, (2) Menimbulkan minat (Interest), infromasi yang disampaikan harus dapat menimbulkan perasaan ingin tahu yang lebih jauh sehingga konsumen mau melihat atau membaca dengan lebih seksama, (3) menimbulkan keinginan (Desire), kebutuhan atau keinginan untuk memiliki, memakai atau melakukan sesuatu harus dibangkitkan, dan (4) membuat tindakan (Action). Terutama untuk usia remaja (berusia 18-29 tahun) dan memiliki tingkat adopsi media sosial tertinggi (90\%), kelompok usia lainnya (Perrin, 2015). Instagram meningkat popularitasnya. Facebook tetap populer di kalangan orang dewasa muda, namun ditinggalkan oleh remaja yang bermigrasi ke instagram dan snapchat. Media sosial secara umumn memerlukan perkenalan dan pemeliharaan hubungan secara online, baik pribadi maupun profesional, melalui berbagai platform.

Hasil penelitian di bidang pemasaran, penggunaan Instagram berusahan membujuk pengguna agar segera melakukan tindakan pembelian, selanjutnya apabila konsumen puas dengan produk yang dibeli, maka akan terjadi pembelian ulang produk yang bersangkutan (Oktaviani \& Fatchiya, 2019).

Dalam konteks Teori Penetrasi Sosial yang menganalisis pengembangan hubungan dari informasi superfisial ke arah yang lebih intim karena penyingkapan diri (Altman \& Taylor, 1973). Instagram sebagai media sosial telah dilakukan oleh remaja untuk menjalin pertemanan, melalui fitur-fitur pertemenan yang ada.

Pola pembicaraan dalam konteks penetrasi sosial mengarah pada topik pembicaraan lebih dalam (depth) akrab dibandingkan pembicaraan yang luas (breadth). Keluasan merujuk pada jumlah topik yang didiskusikan dalam sebuah hubungan, sedangkan kedalaman adalah mengacu pada derajat keintiman (West \& Turner, 2008).

Selanjutnya, Thibaut dan Kelly mengembangkan Teori Pertukaran Sosial yang berasumsi bahwa individu akan secara sukarela tinggal dalam suatu hubungan sosial jika memiliki keuntungan dalam suatu hubungan (West \& Turner, 2008). Aplikasi dari teori 
pengembangan hubungan dalam konteks komunikasi interpersonal, misalnya individu yang saling berkomunikasi melalui Instagram dapat saling Unfollow jika tidak menguntungkan dari segi pengembangan hubungan.

Berdasarkan hubungan dalam dunia cyber memiliki kekuatan individu yaitu, identity fluidity merupakan proses pembentukan identitas di dunia cyber bisa berbeda dengan identitasi dunia maya. Selanjutnya, renovated hierarchie merupakan proses perekaan hierarki di dunia nyata. Information as reality merupakan informasi realita yang hanya berlaku di dunia virtual. Artinya bahwa individu dalam dunia cyber dapat memiliki pribadi dan identitas sama atau berbeda secara offline (Jordan, 1999). Lebih lanjut Stone (1999), mengemukakan bahwa dalam komunitas virtual tidak dapat dipastikan bahwa identitas individu di media online merupakan penggambaran di dunia nyata (Nasrullah, 2012).

Penelitian ini berfokus pada efektifitas penggunaan fitur Instagram dalam meningkatkan pertemanan remaja di era digital. Komunikasi yang dilakukan oleh remaja melalui fitur media sosial Instagram memerlukan keahlian agar berjalan secara efektif. Remaja SMA Negeri 1 Maros mengunakan Instagram didasari oleh faktor internal individu yang terdiri dari kebutuhan mereka untuk mencari informasi dan interaksi sosial. Faktor internal individu atau karakteristik pengakses diduga akan memengaruhi efektivitas penggunaan Instagran dalam bentuk konsep IDA.

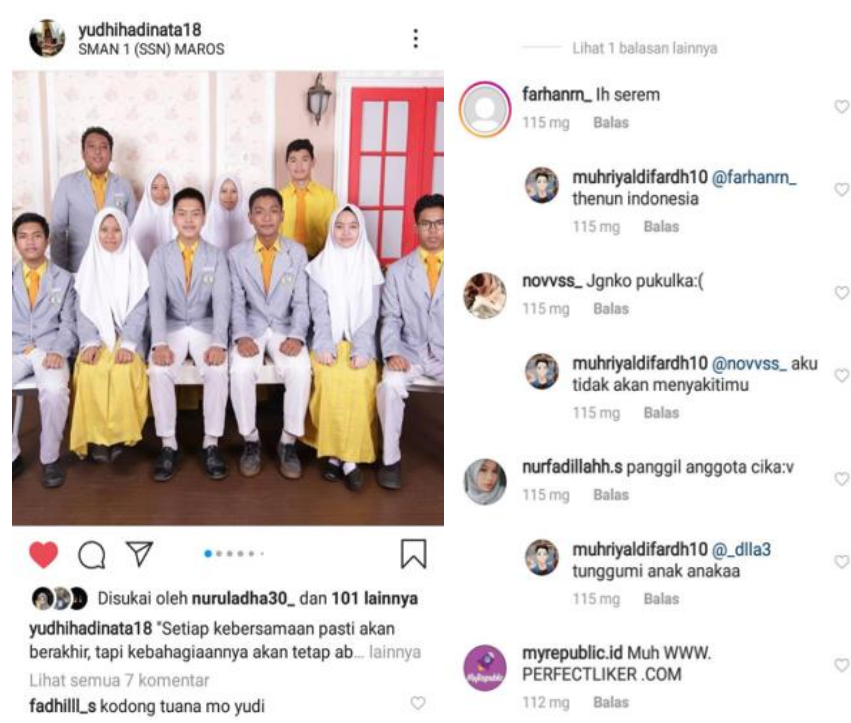

Sumber: Hasil Penelitian, 2020

Gambar 1 Instagram Pertemanan Remaja

Konsep IDA ini merupakan turunan dari konsep AIDA yaitu Attention merupakan upaya untuk mendapatkan perhatian remaja yang terlihat dari perubahan dalam konteks pertemanan. Namun pada penelitian ini seluruh responden telah dianggap perhatian terhadap Instagram mereka. Hal ini dibuktikan dengan responden mem-follow instagram dan mengaksesnya Artinya responden, mengalami masa peralihan dari anak menuju dewasa sangat aktif menggunakan media sosial, dan memanfaatkan fitur Instagram Stories untuk eksistensi diri, jati diri, citra diri, mencari dan mengembangkan hubungan pertemanan, hingga menimbulkan minat responden untuk mencari informasi lebih dalam mengenai pertemanan mereka di instagram. 
Penelitian ini bertujuan untuk mengetahui tingkat efektifitas penggunaan fitur instagram dalam meningkatkan pertemanan, khususnya remaja di SMA Negeri 1 Maros.Penelitian diharapkan memberikan kontribusi positif penggunaan Instagram sebagai media komunikasi dalam menjalin persahabatan yang baik. Sehingga memberikan manfaat bagi remaja saat menggunakan media sosial jenis instagram, melalui fitur yang tersedia.

\section{METODE PENELITIAN}

Penelitian yang berfokus pada efektifitas penggunaan fitur instagram dalam meningkatkan pertemanan remaja di era digital menggunakan pendekatan kuantitatif melalui survey. Penelitian deskriptif kuantitatif menggunakan instrumen pengumpulan data melalui kuesioner terhadap responden yang mewakili populasi tertentu (Kriyantono, 2006). Populasi dalam penelitian ini adalah siswa Sekolah Menengah Atas Negeri 1 Maros yang menggunakan fitur-fitur instagram sebanyak 106 orang yang sekarang duduk di kelas XI. Pemilihan responden kategori sekolah menengah yang termasuk remaja millennial.

Teknik penentuan sampel dilakukan melalui probability sampling, merupakan penentuan sampel yang memberikan peluang sama pada populasi yang ada. Teknik penarikan sampelnya adalah stratified random sampling karena berstrata secara proporsional. Jumlah sampel yang dipilih sebanyak 67 responden berdasarkan Tabel Isaac dan Michael untuk taraf kesalahan 5\% (Sugiyono, 2011).

Pengumpulan data menggunakan kuesioner untuk menjawab permasalahan penelitian. Selanjutnya studi pustaka dengan referensi yang relevan dengan topik penelitian. Analisis tabel frekuensi, merupakan suatu analisis yang dilakukan dengan membagi-bagikan variabel penelitian kedalam kategori yang dilakukan atas dasar frekuensi. Analisis tabel silang, merupakan teknik yang digunakan untuk menganalisa dan mengetahui variabel yang satu memiliki hubungan dengan variabel lainnya sehingga dapat diketahui apakah variabel tersebut bersifat positif atau negatif.

\section{HASIL DAN PEMBAHASAN}

Perkembangan teknologi virtual memunculkan media sosial dalam bertukar pesan, seperti Instagram sebagai alternatif bagi pengguna internet memanfaatkan fitur-fitur pertemanan. Instagram adalah media sosial menawarkan fitur yang digunakan pemilik akun untuk berbagi informasi. Penelitian yang berfokus mengukur efektifitas penggunaan fitur instagram terhadap meningkatkan pertemanan pada remaja di era digital. Penelitian deskriptif kuantitatif yang menganalisis 67 responden siswa SMA Negeri 1 Maros kelas XI.

Berdasarkan karakteristik jenis kelamin menunjukkan perempuan lebih dominan sebanyak 47 (70.1\%) dibandingkan dengan responden berjenis kelamin laki-laki hanya 20 orang (29.9\%). Rata-rata usia responden 16-17 tahun dari keseluruhan jumlah responden remaja pengguna Instagram. Selanjutnya, analisis efektifitas fitur-fitur instagram, maka akan dianalisis durasi dan intensitas tingkat penggunaan fitur instagram oleh responden. Variabel durasi dan frekuensi bertujuan untuk melihat kecenderungan penggunaan fitur Instagram dalam meningkatkan pertemanan dengan sesama pengguna. Berikut gambaran durasi dan intensitas penggunaan fitur-fitur Instagram remaja di era digital, seperti Tabel 1 berikut: 


\section{Tabel 1 Durasi dan Intensitas Penggunaan Fitur-Fitur Instagram}

\begin{tabular}{clll}
\hline \multirow{2}{*}{ Durasi } & $<8$ bulan & $9-11$ bulan & $>1$ Tahun \\
& $11(16.4 \%)$ & $15(22.4 \%)$ & $41(61.2 \%)$ \\
\hline \multirow{3}{*}{ Intensitas } & $1-5$ & $6-9$ & $>10$ \\
& /Minggu & /Minggu & /Minggu \\
& $8(11.9 \%)$ & $11(16.4 \%)$ & $49(73.1 \%)$ \\
\hline
\end{tabular}

Sumber: Hasil Penelitian, 2020

Berdasarkan Tabel 1, menunjukkan bahwa durasi remaja menggunakan fitur-fitur instagram lebih dari 1 tahun sebanyak 51 orang (61,2\%), 9-11 bulan ada 15 orang $(22,4 \%)$, dan kurang dari 8 bulan menggunakan fitur-fitur tersebut hanya sebanyak 11 orang $(16,4 \%)$. Variabel pertama lama durasi dan intensitas lebih dari satu tahun menunjukkan waktu yang lama telah menggunakan fitur dalam mengakses pertemanan.

Efektifitas penggunaan dalam tahap interest tergolong sangat efektif. Hal ini ditunjukan sebanyak $61.2 \%$, dibandingkan dengan 9-11 bulan, responden instagram telah lama menggunakan media sosial ini untuk menjalin pertemanan, sehingga mereka tidak perlu bertemu sacara langsung untuk saling berkomunikasi.

Bentuk pertemanan dikategorikan ada yang umum dan teman spesifik yang telah memiliki kedekatan (proksimity) dengan pengguna lainnya. Responden merasa bahwa fitur instagram sudah mewakili dan membantu dalam menyampaikan informasi diantara mereka. Hal tersebut menjadi point penting bagi responden jalin komunikasi dengan teman mereka, tanpa harus bertemu secara langsung.

Responden juga mengaku intensitas mereka dalam bermain internet atau instagram dalam sehari sangatlah sering, hampir setiap saat ketika ada waktu luang mereka membuka instagram. Lebih dari setengah orang dewasa muda (18-29 tahun) melaporkan menggunakan instagram, sehingga menjadikan mereka grup pengguna Instagram terbesar (Duggan, 2015).

Bentuk pertemanan dikategorikan ada yang umum dan teman spesifik yang telah memiliki kedekatan (proximity) dengan pengguna lainnya. Responden merasa bahwa fitur instagram sudah mewakil dan membantu dalam menyampaikan informasi di antara mereka. Hal tersebut menjadi poin penting bagi responden, karena responden jalin komunikasi dengan teman mereka, tanpa harus bertemu secara langsung.

Variabel kedua adalah intensitas penggunaan fitur-fitur instagram mulai arsip cerita, live video, explore, instagram stories, close friends instagram, dan sorotan. Variabel efektifitas penggunaan instagram meningkatkan pertemanan melalui fitur-fitur yang tersedia. Tingkat keaktifan mengunggah instagram story dan fitur close friends, dapat dilihat pada Tabel 2 berikut :

Tabel 2 Efektifitas Instagram Meningkatkan Pertemanan

\begin{tabular}{ccc}
\hline $\begin{array}{c}\text { Efektifitas Instagram } \\
\text { Meningkatkan Pertemanan }\end{array}$ & Frekuensi & Persentase \\
\hline Arsip Cerita & 4 & 6.0 \\
Explore & 4 & 6.0 \\
\hline
\end{tabular}




\begin{tabular}{ccc}
\hline Instagram Stories & 17 & 25.4 \\
Close Friends & 41 & 61.2 \\
Live Video & 2 & 3.0 \\
Sorotan & 3 & 4.5 \\
\hline Total & $\mathbf{6 7}$ & $\mathbf{1 0 0 . 0}$ \\
\hline
\end{tabular}

Sumber: hasil penelitian, 2020

Berdasarkan data Tabel 2, menunjukkan bahwa responden mayoritas memanfaatkan fitur close friends sebanyak 41 responden (61.2\%). Responden yang memanfaatkan instagram stories sebanyak 17 responden (25.4\%). Fitur-fitur instagram lainnya, seperti arsip cerita, explore, ;ive video, dan sorotan minim digunakan dalam meningkatkan efektifitas pertemanan di kalangan remaja. Tahap desire ini, mencakup kejelasan informasi dan faktor daya tarik.

Pada tahap ini responden menilai bahwa tampilan fitur instagram yang teratur, tulisan, foto dan video yang terlihat sehingga mudah pahami. Selain itu kejelasan informasi dianggap faktor terpenting oleh responden, karena dengan ini responden dapat memperoleh infomasi secara jelas, manarik, dan jelas tanpa harus mencari informasi melalui media lain, ini mereka lakukan melalui fitur closed friend, dibandingkan fitur instagram lainnya. Seperti, berbagi foto-foto di instagram dapat dijadikan kenangan, dapat mengekspresikan keadaan yang sedang terjadi dan telah terjadi. Para responden menginginkan reaksi dari teman-teman mereka dan saling memberikan komentar dan like dari foto maupun video yang diunggah

Pengguna instagram berkesempatan lebih dekat teman, melalui fitur instagram lain, seperti stickers dan boomerang. Pengguna instagram memilih instagram karena selain bisa lebih dekat dengan sesama penggunanya tetapi juga banyak content menarik yang ditawarkan oleh instagram untuk sekedar bersosialisasi, mengunjungi content yang disukai, berbisnis, maupun melakukan aktivitas sehari-hari seperti berekspresi melalui ragam fitur yang dimiliki oleh instagram.

Penggunaan Instagram dapat membantu pengguna membangun komunikasi pertemanan melalui interaksi dengan orang lain sebagai cara untuk menjaga hubungan sosial. Sehubungan dengan perilaku positif, seperti, jalin hubungan personal. Seperti diungkapkan dalam pengungkapan diri (Hollenbaugh \& Ferris, 2014).

Menjalin hubungan terwujud dalam banyak hal, seperti pertemanan atau persahabatan merupakan bentuk relationship yang lebih menekankan pada keadaan saling mengerti, menerima, serta saling memberikan dukungan (Arianto. 2015). Faktor yang menyebabkan tingginya penggunaan fitur close friends adalah atensi sebagai njadi daya tarik responden dalam menggunakan fitur close friends instagram.

Pengguna media sosial untuk mendapatkan informasi tentang orang lain (Lampe \& Ellison et al, 2006). Informasi yang diperoleh membantu mereka mempertahankan hubungan interpersonal, sehingga membantu mereka memenuhi kebutuhan mereka untuk menjadi bagian dari oarang lain. Pengguna lain mungkin menggunakan media sosial untuk bertemu individu yang berpikiran sama serta menerima persahabatan dan dukungan sosial.

Pengguna memperoleh manfaat dari penggunaan media sosial. Untuk dapat berinteraksi atau berkomunikasi dengan orang lain, sebagai media informasi, sebagai media 
berbagi, tempat promosi usaha, dan hiburan. Selanjutnya, atensi penggunaan Instagram sebagai media komunikasi, dalam hal ini Instagram dapat mengakses hingga kebagian yang sangat pribadi. Informasi dapat ditampilkan melalui pesan, gambar, video bahkan live streaming secara langsung.

Fitur Instagram memberikan peluang dan kesempatan untuk lebih dekat followers, sehingga tak ragu menggunakan fitur Instagram. Bentuk atensi penggunaan Fitur close friends, seperti Tabel 3 berikut:

Tabel 3 Atensi Penggunaan Fitur Close Friends Instagram

\begin{tabular}{lcc}
\hline $\begin{array}{c}\text { Atensi Daya Tarik } \\
\text { Penggunaan Fitur Close } \\
\text { Friends }\end{array}$ & $\begin{array}{c}\text { Frekuen } \\
\text { si }\end{array}$ & $\begin{array}{c}\text { Persenta } \\
\text { se }\end{array}$ \\
\hline $\begin{array}{l}\text { Keleluasaan Memilih } \\
\text { Teman }\end{array}$ & 11 & 16.4 \\
\hline $\begin{array}{l}\text { Kenyamanan Mengunggah } \\
\text { Instagram Stories Dalam }\end{array}$ & 13 & 19.4 \\
$\begin{array}{l}\text { Fitur Close Friends } \\
\text { Penyingkapan Diri Lebih } \\
\text { Tinggi }\end{array}$ & 43 & 64.2 \\
\hline \multicolumn{1}{c}{ Total } & $\mathbf{6 7}$ & $\mathbf{1 0 0 . 0}$ \\
\hline
\end{tabular}

Sumber : data primer, 2020

Tabel 3, mengindikasikan bahwa penyingkapan diri lebih tinggi sebanyak 43 orang (64.2\%), Kenyamanan Mengunggah Instagram Stories Dalam Fitur close friends sebanyak 13 orang (19.4\%), dan memiliki keleluasaan memilih teman yang diinginkan sebanyak 11 orang (16.4\%). Hal ini menjelasksan bahwa pada taahapan action, yaitu tahapan penggunaan fitur close friends digunakan sebagai fitur yang menjaga kerahasiaan karena harus ada izin pemilik akun untuk melihat unggahan di instagram. Daftar pertemanan fitur close friends memiliki kerahasiaan sehingga kebocoran privasi memiliki kemungkinan kecil karena daftar pertemanan sudah saling kenal dan percaya. Tingkat keterbukaan lebih tinggi karena kedekatan (proximity) karena memilih orang tertentu yang akan dibagikan unggahannya melalui fitur ini. Interaksi setiap manusia dalam kehidupan sosial selalu berusaha memberikan gambaran terbaik dirinya melalui tampilan aktivitas komunikasi. Aktivitas komunikasi tatap muka baik secara verbal maupun nonverbal dilakukan untuk mengkonstruksi diri dalam wujud pengungkapan dan aktualisasi diri (Arianto, A, 2019). Selain itu faktor kelengkapan informasi menjadi faktor terpenting dalam tahap pengambilan keputusan, karena responden akan terus mencari informasi tentang semua hal yang terkait pertemanan mereka. Aktivitas yang diungkapkan pengguna menjadi jalan untuk mereka berkomunikasi, misalnya saling memberikan komentar pada foto ataupun status yang diunggah pengguna media sosial.

Fitur close friends terbukti dapat mengefektifkan pertemanan di kalangan remaja karena memiliki kesenangan tersendiri dalam bentuk kedekatan dan kepercayaan. Penyingkapan diri dalam fitur ini diakibatkan adanya kesadaran diri (self awareness). Karakteristik fitur close friends menyebabkan orang saling berbagi informasi, dan dapat membangun hubungan dari superficial untuk lebih dekat dan mendalam bagi kedua belah 
pihak. Bagi remaja, diterima oleh teman sebayanya merupakan suatu kebutuhan (Santrock, 2011) Oleh karena itu, teman sebaya menjadi salah satu sumber dukungan sosial yang dibutuhkan dalam menjalani proses dan dinamika masa remaja. Media sosial, dapat menjadi wadah bagi individu untuk menyatakan dukungan sosial. (Aristantya \& Helmi, 2019)

Platform media sosial, sebagian besar dalam kaitannya dengan penggunaan instgaram, telah berpusat pada nilai sosial karena berkaitan dengan interaksi dan terhubung dengan teman-teman. Misalnya, studi sebelumnya di instagram menunjukkan bahwa terhubung dan tetap berhubungan dengan teman, keluarga, dan pertemanan; menjaga ikatan sosial; dan mengikuti teman-teman lama, di antara motivasi lain yang relevan secara sosial adalah motif utama untuk menggunakan platform seperti instagram.. Media Instagram ini berperan untuk menarikpara pengguna agar menggunakan medianya suntuk suatu aktivitas pertemanan atau pemuas kebutuhan sosialisasi, dan berperan aktif dalam menyeleksi informasi yang disebarkan, tidak langsung menerima informasi begitu saja.

Inti dari pertemanan adalah faktor keterbukaan hubungan timbal balik, untuk saling menyingkapkan diri lebih terbuka. Efek diadik merupakan faktor yang berpengaruh pada penyingkapan diri karena timbulnya rasa nyaman dalam membuka diri (Devito, 1997). Tingkat besaran kelompok yang terlibat dalam fitur close friends, juga menentukan efektifitas pertemanan. Asumsinya bahwa penyingkapan diri akan lebih efektif dalam kelompok kecil dibandingkan dengan kelompok besar. Hal ini dikarenakan dalam kelompok besar penyingkapan diri lebih sulit karena tanggapan yang muncul berbeda dari setiap anggota kelompok. Selanjutnya, topik bahasan memiliki kecenderungan semakin umum seseorang akan cenderung membuka diri, misalnya topik pekerjaan atau hobi. Penyingkapan diri lebih minim membuka permasalahan personal seperti kehidupan seks atau situasi keuangan. Artinya bahwa semakin pribadi dan makin negatif suatu topik, makin kecil kemungkinan pengungkapannya Devito (1997). Pengungkapan diri (self disclosure) merupakan sebuah aktivitas atau proses berbagi informasi dengan orang lain.

Seperti, Informasinya menyangkut pengalaman pribadi, perasaan, rencana masa depan, impian dan lain-lain. Dalam kehidupan sehari-hari pengungkapan diri (self disclosure) tidak hanya terjadi dalam komunikasi dan interaksi secara langsung, namun juga dapat terjadi pada media perantara yakni media sosial, seperti yang dilakukan individu melalui media sosial instagram.

Instagram adalah jejaring sosial yang digunakan sebagi tempat menyebarkan dan berbagi informasi tentang diri pengguna, berinteraksi dengan orang banyak, serta dapat mengenal lebih dekat dengan sesama pengguna Instagram melalui foto-foto, video yang diunggah.

Remaja memanfaatkan Instagram sebagai sarana dalam mencari jati diri. Remaja yang menggunakan media sosial Instagram, memanfaatkan berbagai macam fasilitas yang dimiliki oleh Instagram untuk mengkontruksi identitas dirinya, dan sebagai wadah untuk unjuk diri. Pembentukan identitas diri dalam media sosial instagram tersebut dipengaruhi oleh pikiran, pengalaman, dan masyarakat (Sakti \& Julianto, 2019). Hal tersebut menunjukkan bahwa pengguna instagram lebih menekankan pada koneksitas dengan orang lain dan lebih banyak tentang identitas pribadi dan promosi diri, selain motif lain, termasuk pengawasan dan pengumpulan pengetahuan tentang orang lain, dokumentasi peristiwa kehidupan dan 
kesejukan pertemanan, yang mencakup promosi diri dan menampilkan kreativitas seperti keterampilan fotografi.

Selain itu, pengguna instagram juga dapat memiliki hak kepemilikan konten di instagram. Instagram tidak mengklaim hak kepemilikan dalam teks, file, gambar, foto, video, suara, karya musik, karya tulisan, aplikasi, atau bahan lain yang di-posting oleh pengguna. Studi khusus ini menemukan bahwa pengawasan adalah motivasi terkuat untuk penggunaan Instagram.

\section{SIMPULAN}

Sangat efektif dalam penggunaan fitur Instagram dalam meningkatkan pertemanan remaja SMA Negeri 1 Maros dalam tahapan interest adalah 61.2\%. Efektif dalam durasi dan intensitas penggunaan, tahapan desire sebesar $25,4 \%$ dalam proses komunikasi dalam konteks pertemanan, melalui fitur Instagram Stories, dibandingkan fitur arsip cerita, explore, live video, instagram stories, close friends, dan sorotan. Tahapan action sebesar 64,2\% untuk fitur ini memberikan konsep penyingkapan diri dan kenyamanan mengunggah instagram stories dalam proses pertemanan mereka tanpa harus mencari informasi melalui media lain. Efektifitas penggunaan fitur instagram sebagai media komunikasi dalam meningkatkan pertemanan, bersesuaian aspek keterbukaan dan kedekatan dalam memilih dan membagikan unggahan, bersifat privasi dan kebebasan memilih teman yang diinginkan dalam proses meningkatkan pertemanan.

Hal ini bersesuaian bahwa menggunakan instagram merupakan suatu situs aplikasi yang dijadikan sebagai tempat untuk berkomunikasi dengan teman-teman yang ada di dunia nyata dan maya. Sehingga berperan sebagai media berbasis internet untuk saling berbagi ide, menciptakan kreasi, dan membangun komunitas melalui konten berupa pesan, gambar, dan video.

\section{UCAPAN TERIMA KASIH}

Penulisan mengucapkan terima kasih kepada para siswa/siswi SMA Negeri 1 Maros yang bersedia dilibatkan sebagai responden pada penelitian ini. Demikian pula pihak yang telah membantu menyelesaikan maskah jurnal ini, terutama bagi tim reviewer Jurnal Avant Garde banyak memberikan masukan dan arahannya, tidak dapat saya sebutkan satu-persatu. Semoga segala dukungan dan bantuan yang telah diberikan kepada penulis dapat bernilai amalan. Akhir kata, semoga tulisan ini dapat bermanfaat dan memberi inspirasi serta dapat menjadi referensi yang berarti bagi pihak yang membutuhkan. 


\section{DAFTAR PUSTAKA}

Armi, Nur. (2019). Self Disclosure Melalui Aplikasi Hello Yo dan Interkasi Langsung Antar Pengguna Untuk Menjalin Keakraban. Skripsi tidak diterbitkan. Makassar: Fisip Universitas Hasanuddin.

Arianto, A. (2015). "Menuju Persahabatan" Melalui Komunikasi Antarpribadi Mahasiswa Beda Etnis (Studi Kasus Di Fakultas Ilmu Sosial Dan Ilmu Politik Universitas Tadulako). KRITIS: Jurnal Ilmu Sosial dan Ilmu Politik Universitas Hasanuddin, 1(2), 219-230

(2019). Studi Dramaturgi Dalam Presentasi Diri Kelompok Jamaah An-Nadzir Kabupaten Gowa. Jurnal ASPIKOM, 4(1), 96-112.

Aristantya, E. K., \& Helmi, A. F. (2019). Citra Tubuh pada Remaja Pengguna Instagram. Gadjah Mada Journal of Psychology (GamaJoP), 5(2), 114. https://doi.org/10.22146/gamajop.50624

Asosiasi Penyelenggara Jasa Internet Indonesia. (2018). Laporan Survey Penetrasi \& Profil Perilaku Pengguna Jasa Internet Indonesia. Jakarta : APJII. (2020). Laporan Survey Penetrasi \& Profil Perilaku Pengguna Jasa Internet Indonesia. Jakarta : APJII

Carr, C. T., \& Hayes, R. A. (2015). Social media: Defining, devel- oping, and divining. Atlantic Journal of Communication, 23, 46-65.

Dari, U. (2019). Ini dampak positif \& negatif penggunaan Instagram di kalangan milenial. Https://Www.Brilio.Net/Creator/Ini-Dampak-Positif-Negatif-Penggunaan-InstagramDi-Kalangan-Milenial-4963d5.Html.

Devito, Joseph. A. (1986). The Interpersonal Communication. $4^{\text {th }}$ Edition. New York: Herper and Row Publisher. 1997. Komunikasi Antarmanusia : Kuliah Dasar. Edisi Kelima. Jakarta : Profesional Books.

Duggan, M. (2015a). The demographics of social media users. Pew Research Center. Retrieved from http://www.pewinternet. org/2015/08/19/the-demographics-of-socialmedia-users/

Ellison, N. B., \& boyd, d. (2013). Sociality through social network sites. In W. H. Dutton (Ed.), The Oxford handbook of Internet studies (pp. 151-172). Oxford, UK: Oxford University Press.

Gafar, Abdoel. (2008). Penggunaan Internet sebagai Media Baru. Jurnal Ilmiah Universitas Jambi. Vol 8 (2)

Hollenbaugh, W. E., \& Ferris, A. L. (2014). Facebook self-disclo- sure: Examining the role of traits, social cohesion, and motives. Computers in Human Behavior, 30, 50-58.

Johnson, D. W. (1981). Reaching Out Interpersonal Effectiveness and Self-Actualization. Englewood Cliffs: Prentice Hall.

Kriyanto, R. (2006). Riset Komunikasi (pert). Jakarta: Kencana Pernda Media Grup.

Lampe, C., Ellison, N. B., \& Steinfield, C. (2006). A face(book) in the crowd: Social searching vs. Social browsing. In Proceed- ings of the 2006 20th Anniversary Conference on Computer Supported Cooperative Work (pp. 167-170). 
Mahendra, Bimo. Eksistensi Sosial Remaja Dalam Instagram (Sebuah Perspektif Komunikasi). (2017). Jurnal Visi Komunikasi/Volume 16, No.01, Mei 2017: 151 160.

Maryolein, S., Dwina Hapsari, N., \& Oktaviani, R. C. (2019). Instagram Sebagai Media Publikasi Dalam Membangun Brand Awareness Jakarta Aquarium. Avant Garde, 7(1), 19. https://doi.org/10.36080/avg.v7i1.849

Nofha Rina, S. N. F. (2020). Literasi Media Digital: Efektivitas Akun Instagram @infobandungraya Terhadap Pemenuhan Kebutuhan Informasi Followers. MEDIALOG: Jurnal Ilmu Komunikasi, 3(1), 13-24. https://doi.org/10.35326/medialog.v3i1.479

Nasrullah, Rulli. (2012). Komunikasi Antar Budaya (Di Era Budaya Siber). Jakarta: Kencana Prenada Media Group. .(2013). Cyber Media. Yogyakarta: Idea (2015). Media Sosial. Bandung: Simbiosa Rekatama Media.

Oktaviani, W. F., \& Fatchiya, A. (2019). Efektivitas Penggunaan Media Sosial Sebagai Media Promosi Wisata Umbul Ponggok, Kabupaten Klaten. Jurnal Komunikasi Pembangunan, 17(1), 13-27. https://doi.org/10.29244/jurnalkmp.17.1.13-27

Pertiwi, Wahyunanda Kusuma. (2018). Fitur “Close Friends" Instagram Stories Kini Dipakai oleh Semua.

(https://tekno.kompas.com/read/2018/12/02/08180067/fitur-close-friends-instagram-storieskini-bisa-dipakai-oleh-semu. Diakses 11 Juni 2020.

Perrin, A. (2015). Social media usage: 2005-2015. Pew Research Center: Internet, Science \& Tech. Retrieved from http:// www.pewinternet.org/2015/10/08/social-networkingusage-2005-2015/

Wahyunanda, Kusuma Pertiwi (2017). Motif Penggunaan Media Sosial Instagram Di Kalangan Remaja. Communication, 8(1), 51. https://doi.org/10.36080/comm.v8i1.651

Sugiyono. (2011). Metode Penelitian Kuantitatif, Kualitatif, Dan $R \& D$. Bandung : ALFABETA

Sagiyanto, Asriyani dan Ardyanti, Nina. (2018). Self Disclosure melalui Media Sosial Instagram (Studi Kasus pada Anggota Galeri Quote). Nyimak Journal of Communication Vol. 2 (1)

Syahrul, Irawati. (2019). Studi Naratif Remaja Berkepribadian Introvert Pada Fitur Close Friends Instagram Komunitas EverLasting Friends di Kota Makassar. Skripsi tidak diterbitkan. Makassar: Fisip Universitas Hasanuddin.

SMAN 1 Maros. (2017). Profil dan Sejarah Singkat SMAN 1 Maros. (http://sman1 maros.sch.id/profil.php?id=profil\&kode=12\&profil=Sejarah\%20Singkat. Diakses pada 4 Mei 2020 pukul 21.30 WITA.

Sakti, B Cahya. Yulianto. (2015) Penggunaan Media Sosial Instagram Dalam Pembentukan Identitas Diri Remaja Jurusan Ilmu Komunikasi Fakultas Ilmu Sosial dan Ilmu Politik Universitas Diponegoro

West, Richard dan Lynn H. Turner. (2008). Introducing Communication Theory: Analysis and Application, 3 Ed. Penerjemah Maria Natalia Damayanti Maer. 2009. Pengantar Teori Komunikasi Analisis dan Aplikasi Edisi 3. Jakarta: Salemba Humanika. 